\title{
Erratum to: Role of German-speaking scholars in the development of pathology in Turkey
}

\author{
Nadir Paksoy
}

Published online: 11 June 2019

(c) Springer-Verlag GmbH Austria, ein Teil von Springer Nature 2019

\section{Erratum to:}

Wien Med Wochenschr 2019

https://doi.org/10.1007/s10354-019-0686-y

Unfortunately, the legend of Fig. 2 contained a mistake. Please find the correct one below.

The correct year dates of Dr. Rigler's stay in Istanbul, published on page 4 of the original version, must be as follows:

Dr. Lorenz Rigler, (1815-1862), who was sent to Istanbul by the Austrian government for the organization of Turkish military hospitals, worked as a lecturer at the medical school between 1849 and 1856 .

The name of Prof. Philipp Schwartz has been represented erroneously in a false spelling. The correct spelling is Prof. Philipp Schwartz.

The online version of the original article can be found under https:// doi.org/10.1007/s10354-019-0686-y.

\section{Prof. Dr. N. Paksoy, MD MIAC ( $ه)$}

Department of Pathology, Faculty of Medicine, University of Kocaeli, Izmit, Kocaeli, Turkey

Cytopathology/FNA Private Practice, Hurriyet Cad. Safak, Apt: 125/17, 41300 Izmit, Kocaeli, Turkey nadirpaksoy@gmail.com

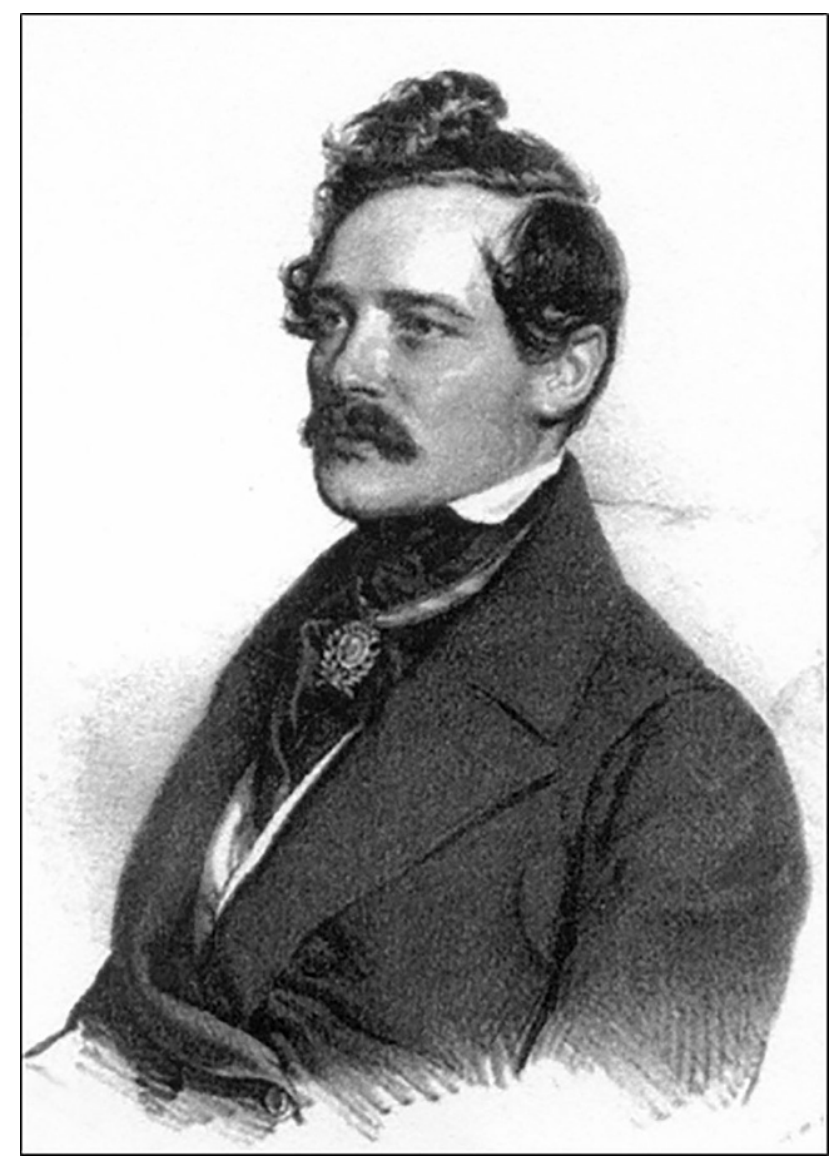

Fig. 2 Sigmund Spitzer (1813-1894) from Vienna. Professor of Anatomy by 1839 and Director of the Imperial Medical School, Galata Serai, Istanbul from 1839 to 1850 . (From the collections of the Medical University of Vienna. Reprinted with permission from Professor Gulten Dinç, Head of the Department History of Medicine, Istanbul-Cerrahpasa University, Medical Faculty) 